\title{
MUNICH 1938 AND CHANGES OF EDUCATION IN CZECH LANDS
}

\author{
Lubomír Nenička
}

\begin{abstract}
This paper deals with some aspects of the history of Czech education in the post-Munich era. The most attention is paid to the consequences of the Munich Treaty for Czech education. The service to the nation was presented as the key principle of quality of education during the Second Republic. A typical feature of changes in the post-Munich era was the growth of nationalism and growing influence of the Catholic Church.
\end{abstract}

\section{Key words}

Munich Treaty, second republic, education, Catholicism, nationalism.

\section{Mnichov 1938 a proměny vzdělávání v Českých zemích}

\begin{abstract}
Abstrakt
Př́spěvek se zabývá některými aspekty vývoje českého vzdělávání v pomnichovském období. Hlavní pozornost je věnována důsledkům príjetí Mnichovské dohody pro české školství. Jako hlavní princip kvality vzdělávání v době druhé republiky byla prezentována služba národu. Typickým rysem změn v pomnichovské éře byl nárůst nacionalismu a rostoucí vliv katolické církve.
\end{abstract}

\section{Klíčová slova}

Mnichovská dohoda, druhá republika, vzdělávání, katolicismus, nacionalismus.

\section{Introduction}

The Acceptation of the Munich Treaty belongs to the most tragic moments in the whole Czech nation's history. The sacrifice, the Czechoslovakia was forced to make, questioned its principles of being and foreign political tendencies. Under the impression of the "Munich Trauma" the new political representation 
cast aside Masaryk's "humanitarian ideals" and its new politics began to be governed by a general conviction that all the thinking and doing should be submitted to the interest of the independently determined nation. These tendencies infiltrated all parts of the public life - including the education.

This paper tries to introduce the post-Munich Treaty development of the education in Czechoslovakia. It describes briefly the main practical problems and recurrences associated with the changes in national borders. Furthermore it exemplifies the main conception of the new objectives and tasks of the Czechoslovak educational system while in the same time it shows in short examples how these conceptions were being put in practice. Limited text length of this paper however only allows it to show just an ideological outline of the changes in the Czechoslovak educational system during the post-Munich Treaty period and possibly determines the orientation of further research works.

\section{Munich Treaty Aftermath and the Czechoslovak educational system}

The results of the Munich treaty afflicted the Czechoslovak educational system as strongly as they afflicted the other parts of public life. The operation of particular types of schools had already been afflicted distinctively by the dramatic events that took place in the second half of September 1938. The opening of the new school year was made impossible by the general mobilization. Lots of school buildings were temporarily seized for military purposes. In the concrete the basic schools were evicted and given over to the army. The teachers were called up or joined the civil authorities to help. ${ }^{1}$ Also the college students were called up in the time of the general mobilization and student's houses and campuses were used for military purposes. It was why the Ministry of Education and National Edification decided to cast aside enrolment for the winter half and dates of all examinations. ${ }^{2}$ When the extraordinary circumstances were overcome the schooling was started again.

Even after that the Czechoslovak educational system had to face lots of practical problems associated with territorial changes. Among the refugees and evacuees from occupied areas were lots of students and pupils from different types of schools. Just the number of secondary school students increased with $15 \% .^{3}$ Lots of schools in the occupied areas were closed down and employees

\footnotetext{
${ }^{1}$ Státní okresní archiv Frýdek-Místek (SOkA), f. Obecná škola dívčí ve Frýdku, Školní kronika, inv. n. 1.

${ }^{2}$ MATES, P. K situaci na vysokých školách.. (1989), p. 101.

${ }^{3}$ GEBHART, J. - KUKLÍK, J. (2004), p. 204.
} 
had to find new places of work in the Czech interior. ${ }^{4}$ The Teacher's boards came up with lots of proposals how to solve the hard situation of refugees, head of which were the requirements for pensioning all teachers older than 55 years with more than 35 years of service and banning the employment of married female teachers. ${ }^{5}$

In the end of October 1938 the parliamentary saving and control committee put a proposal to the government in which it pressed on accelerated solving of the question of married women's employment. The application of the proposal was granted by the Statutory Order nr. 379 from $21^{\text {st }}$ December which among other formulated rules for dismissal of married women and otherwise secured female employees. They could either leave at their own request or be dismissed even if they had already reached for tenure. The same Statutory Order also made a decision on vacation of civil servants who superannuated under the newly introduced conditions. ${ }^{6}$ The age limit for teachers was decreased from 70 to 65 years. In the coming year the age limit was due to decrease even lower. ${ }^{7}$ The decision to pension before time the civil servants influenced the situation in the educational system rather in the bad way. The results were felt especially by the colleges from where the highly reputable experts were due to leave during the year 1939. Representatives of particular faculties warned openly of the problems concerned with the compulsory retirement of erudite professors. Even the press, which would under different circumstances welcome the changes, expressed certain doubts. For example according to Lidové Listy the pensioning before time of 40 college professors who had to leave until June 1939 could have a affect undesirably the standard of Czechoslovak college education. ${ }^{8}$ The college life was to be affected even more by the forthcoming law which the government's intention to circumscribe autonomous status of colleges. However the sudden end of the second republic prevented these plans from being implemented. ${ }^{9}$

The enthronement of the new regime was in the first place accompanied by a discussion on the necessity of reformation of the educational system. Particularly in the case of the high school system several different lines of thought were pursued which demanded conformation of the system to the new

\footnotetext{
${ }^{4}$ See for example KURAL, V.- RADVANOVSKÝ, Z. (2002) or MIKA, J. (1992).

${ }^{5}$ Teachers proposals see for example Zemský archiv v Opavě (ZAO), f. Policejní ředitelství v Moravské Ostravě - relace ze schůzí, kart. 1241, sign. 439.

${ }^{6}$ MATES, P. Projevy fašizace.. (1989), pp. 171-172.

${ }^{7}$ ŠIMŮNEK, M. (2002), p. 107.

${ }^{8}$ Změny na vysokých školách. Lidové listy 21. 1. 1939, p. 4.

${ }^{9}$ MATES, P. K situaci na vysokých školách... (1989), p. 101.
} 
circumstances. Supporters of one of the lines of thought recommended that the system should focus on elite-oriented education of "leaders" capable of leading the "diligent crowds". ${ }^{10}$ According to the supporters of the other line of thought the education should have had a practical effect in the first place and enable the students to assert themselves in the industry or trade. One of the most distinctive speakers for the line of thought was the entrepreneur Jan Antonín Bata who proposed the creation of "comprehensive job-related schools" working on the principle of "industrial and trade organization". According to him the schools for children between 14 to 17 years of age should have been incorporated with particular industrial concerns and the education should result from practice just as the needs "of the nation in our situation" demanded. ${ }^{11}$

He elaborated this utilitarian approach in daily newspapers. This entrepreneur from Zlin for example proposed to use the newly created working units to educate the youth. Joining up these units should have been compulsory even for high school and college students who could continue their education in the camps. ${ }^{12}$ In one of his papers Bata also suggested to file the young unemployed teachers as well. Thanks to joining up the teachers would undergo the "school of work" and begin to be "excellent experts in life" which would also heighten their prerequisite for educating the youth..$^{13}$ The necessity of practical education was emphasized in a speech by the PM Beran during the meeting of secretaries of the Strana národní jednoty/ National Union Party (SNJ/NUP) which was the ruling party at the time. According to him the educational system should have been transformed in such a way that it would lead the youth towards choices of "practical occupations". ${ }^{14}$ The PM spoke in the same spirit at the meeting of the National Front of Youth in Brno in the end of January 1939. He emphasized at the same time the importance of religious values and of the St. Wenceslas Tradition. ${ }^{15}$ These words indicate in which direction the thoughts about the changes of the Czechoslovak educational system also went.

\section{Efforts to ideological changes in the Czech education}

The discussion over reform of educational system made a part of postMunich reflection on deeper ideological changes in the education. According to

${ }^{10}$ VESELÁ, Z. (1992), pp. 106-107.

${ }^{11}$ Ibidem p. 107.

${ }^{12}$ Co máme dělat urychleně. České slovo (ČS) 12. 10. 1938, no. 282, p. 3.

${ }^{13}$ Pro lepší budoucnost našich dětí. ČS 9. 11. 1938, no. 310, p. 2.

${ }^{14}$ GEBHART, J. - KUKLÍK, J. (2004), p. 45

${ }^{15}$ Velký projev predsedy vlády Berana v Brně. A-Zet 30. 1. 1939, pp. 1-2 
the SNJ's blueprint papers the youth should have been educated in the national and Christian spirit. Also the curricula and text books should have been created in such a spirit. ${ }^{16}$ The changes in education were also marked with the postMunich show-down with the First Republic to which the first two Czechoslovak presidents were fell victims in the symbolic level or their portraits respectively. Upon the Government order the portraits of especially president Beneš should have been taken away from all classes and studies. In the Ostrava region his portraits began to disappear during the January and February 1939. It was the tendency in the government's official position towards Tomáš Garrigue Masaryk to dissociate with the unwanted heritage of the First Republic as well as the regards for Masaryk's still living authority and popularity ${ }^{17}$ It was why his portraits could remain in the public rooms including school classes but only if accompanied with portraits of other important personas of Czech history. The lack of respect for the first Czechoslovak presidents was accepted mostly with discountenance evidence of which can be commentaries in many left-wings and centric newspapers or records in school chronicles, for example chronicle of the basic school in Frýdek does not hide bewilderment due to the sudden impeachment of the importance of Tomás Garrigue Masaryk. The author of the record wonders how the "founder of the state, previously worshiped was suddenly dropped ".$^{18}$ The supporters of opposite opinions at some colleges however acted openly. The hatred against Tomáš Garrigue Masaryk was expressed most clearly in the beginning of November by taking down of Masaryk's bust in the Philosophic Faculty's hall done by a student, member of the fascist Vlajka. ${ }^{19}$

The portraits of Czechoslovak President hanging in the class rooms began to be replaced with crosses as symbols of the post-Munich movement towards the Catholicism, which should create one of the pillars for the new Republic. Soon after Munich the Catholics began to pursue the hanging out of the crosses as a symbol of the religious renaissance which was to put the new Czechoslovakia on basis of catholic principles. The introduction of catholic symbols was a part of a widely conceived "cultural revision" which was to clean the Republic of the already unwanted heritage of the Masaryk's and Beneš's pre-Munich Czechoslovakia.

\footnotetext{
${ }^{16}$ GEBHART, J. - KUKLÍK, J. (2004), p. 204.

${ }^{17}$ The attitude of post-Munich Government toward TGM describes FEIERABEND, L. K. (1994), p. 79.

${ }^{18}$ SOkA, f. Obecná chlapecká škola ve Frýdku, školní kronika, inv. n. 1.

${ }^{19}$ Report of police office in Prague. Národní archiv v Praze, f. Prezidium ministerstva vnitra, kart. 1299, sign. X/V/5.
} 
The introduction of the education in thoroughly catholic spirit besides the hanging out of the crosses included also compulsory religious education as well as recourses for atheistic teachers but struck on the reticent position of the Ministry of Education and the agrarian wing inside the SNJ. ${ }^{20}$ It was however typical for these thoughts to have remained in the general, declarative level.

The cultural purification should have struck as well the school libraries from where various improper documents and text books should have been discarded. It was however left for the teachers to decide on the relevant changes in the schooling. In the end of November after being questioned over the case The Ministry of Education stood reticent. It admitted that the new conditions may have some influence on curriculum and would therefore ask for due modifications in text books but on the other hand refused wholesale and hasty change of textbooks particularly because the new conditions have not "settled down". The teachers themselves should in due way clarify all possible discrepancies. ${ }^{21}$ The forthcoming education reform, introduced by the Minister of Education and National Edification Jan Kapras in the beginning of the year 1939 was to decide about the changes in schooling. It was a part of the reform to establish a text book provisioning committee. The substance should have been first of all national and catholic but should in the same time conform to the "needs of practical life". ${ }^{22}$

Within the context of the request for revision of the text books some diatribes appeared in the catholic press against progressive teachers whose positions did not conform to the changed conditions. For example the head representative of the People's Party Bohumil Stašek believed that the previously invocated humanity without proper national substance could not form the basis of education. Only the St. Wenceslas ideal could have formed such a new basis. ${ }^{23}$ The efforts to strengthen the catholic substance of education were accompanied by a raise of nationalism and anti-Semitic tendencies began to enforce themselves. In the beginning of the year 1939 the Ministry of Education and National Edification issued an order upon which the public high

\footnotetext{
${ }^{20}$ RATAJ, J. (1997), pp. 136-137.

${ }^{21}$ Order of Provincial School Board from November 30th. 1938. Moravský zemský archiv v Brně (MZAB), f. Zemská školní rada, kart. 173.

${ }^{22}$ Reformy národní výchovy. Lidové listy 31. 1. 1939, pp. 1-2.

${ }^{23}$ Bohumil Stašek: List k českým učitelům. Lidové listy 19. 1. 1939, p. 1. During the Nazi occupation, religious instruction was banned. In detail see for example MIZIA, C. A. (2007), p. 40.
} 
schools and teachers colleges had to present a list of all Jewish employees, i.e. of all whose parents claimed themselves to the Jewish religion or nationality. ${ }^{24}$

Such measures have brought the Czechoslovak educational system dangerously close to the racial tendencies at the time openly enforced in the remaining German schools in the post-Munich Czechoslovakia. These tendencies however penetrated the Czech environment more likely under foreign pressure and had in fact no influence on operation of schools.

\section{Epilogue}

The post-Munich Treaty development of Czechoslovak educational system was originally affected by practical problems of preparation for war and later by results of territorial changes. As early as in the time of the general mobilization lots of schools were emptied and given over to the army. Vis-a-vis the flow of students and teachers from border areas some non-standard solutions had to be adopted such as concentration of several schools into one building, introduction of alternate schooling or partition of school classes. The educational system was directly affected by the Statutory Order over early retirement of public servants.

The necessity to re-educate the young in spirit of Christian and national doctrine proclaimed by the representatives of SNJ headed by integral Catholics should have expressed itself in the fundamental changes of education, while in the same time even the Czech environment began to be inspired by foreign utilitarian tendencies of totalitarian educational systems, that had to educate the young towards the practical service to the national complex. The short time given to the Second Republic however did not allow these tendencies to develop. The education was in fact changing under the influence of ideological re-evaluation of the educational system; local conditions however did not much come along the actual laying of the new foundations. To restore the schooling and develop it under the conditions of general gloominess was a goal hard enough to achieve with which the request for re-education could not compete. Even though some tendencies, especially in the higher grades of schools began to push themselves thus outlining the development of the education in Czechoslovakia during the reign of totalitarian regimes.

\footnotetext{
${ }^{24}$ Instruction of the Ministry of Education from February $13^{\text {th }}$. 1939. MZAB, f. Zemská školní rada, kart. 174.
} 


\section{Literature}

FEIERABEND, Ladislav Karel. Politické vzpominky I. $1^{\text {st }}$ ed. Brno: Atlantis 1994, 480 pp. ISBN 80-7108-071-3.

GEBHART, Jan - KUKLÍK, Jan. Druhá republika 1938-1939. Svár demokracie a totality v politickém, společenském a kulturním životě. $1^{\text {st }}$ ed. Praha-Litomyšl: Paseka 2004, 320 pp. ISBN 80-7185-626.

KUKLÍK, Jan. Lámání ducha. Školství v „autoritativní demokracii“. Dějiny a současnost. 2009, volume 31, no. 3, pp. 30-32. ISSN 0418-5129.

KURAL, Václav - RADVANOVSKÝ, Zdeněk: „Sudety“ pod hákovým křižem. K dějinám Řišské župy Sudety 1938-1945. $1^{\text {st }}$ ed. Ústí nad Labem: Albis International. 2002, 547 pp. ISBN 80-86067-66-1.

MATES, Pavel. K situaci na vysokých školách v obdobi II. republiky. In: Acta Universitatis Carolinae-Historia Universitatis Carolinae Pragensia. 1989, volume 29, pp. 101-112. ISSN 0323-0562.

MATES, Pavel. Projevy fašizace v českých zemích za tzv. druhé republiky. Právněhistorické studie. 1989, volume 30, pp. 157-184.

MIKA, Janusz: Těšinsko v období mnichovské krize. Diplomová práce. Bratislava 1992.

MIZIA, Cezary Andrzej. Význam Agapé pro pronásledovanou církev podle Josefa Zvěriny. $1^{\text {st }}$ ed. Karviná: OPF SU, 2007, 191 pp. ISBN 978-80-7248-414-0.

RATAJ, Jan. O autoritativní národní stát. Ideologické proměny české politiky $v$ druhé republice 1938-1939. $1^{\text {st }}$ ed. Praha: Karolinum, 1997, 251 pp. ISBN 80-7184-516-7.

ŠIMU゚NEK, Michal. „Mládí vpřed“ a lékařská fakulta Univerzity Karlovy v Praze 1938-1939. Acta Universitatis Carolinae-Historia Universitatis Carolinae Pragensis. 2002, volume XLII, no. 1-2, pp. 105-122. ISSN 0323-0562.

VESELÁ, Zdena. Vývoj české školy a učitelského vzdělání. $1^{\text {st }}$ ed. Brno: Masarykova univerzita, 1992, 147 pp. ISBN 80-21004-58-4.

\section{Archival Resources}

Národní archiv v Praze, fond Prezidium ministerstva vnitra

Státní okresní archiv ve Frýdku-Místku, fond Obecná dívči škola ve Frýdku, fond Obecná chlapecká škola v Místku

Zemský archiv v Brně, fond Zemská školní rada v Brně

Zemský archiv v Opavě, fond Policejní ředitelství v Moravské Ostravě 


\section{Press}

A-Zet 1939
České slovo 1938
Lidové listy 1938-1939

\section{Contact Address:}

Mgr. Lubomír Nenička,

Slezská univerzita v Opavě,

Obchodně podnikatelská fakulta v Karviné,

katedra společenských věd,

Univerzitní náměstí 1934/3,

73340 Karviná,

tel. 732507 767,

nenicka@opf.slu.cz 